\title{
Russian SMEs in achieving sustainable development goals
}

\author{
Evgeny Biryukov ${ }^{1, *}$, Olga Elina ${ }^{1}$, Yury Lyandau${ }^{1}$, and Nicholay Mrochkovskiy ${ }^{1}$ \\ ${ }^{1}$ Plekhanov Russian University of Economics, 36, Stremyanny lane, 117997, Moscow, Russia
}

\begin{abstract}
This article examines trends and opportunities in implementing the concept of sustainable development in the world and in the economy of the Russian Federation at the level of small and medium-sized enterprises. Based on the analysis of statistical data on contribution and forms of participation in solving environmental problems and formation of sustainable development trends in terms of achieving the SDGs of SMEs in the Russian Federation, we conclude that there is insufficient participation and weak motivation in this sector. The analysis is done using data from Eurostat, Rosstat, and Fedstat (an OECD institutional website), studying how values of indicators have changed during recent years. This conclusion is in line with studies of global trends showing a decline in business and economic activity towards the achievement of the SDGs, especially in the SME sector. At the same time, we show the existence of business niches and significant growth potential in this sector. In conclusion, we consider possibilities for overcoming these trends through external influence in the form of government support and through internal transformation of business processes. Furthermore, we propose business models for implementing participation of small and medium-sized businesses in the formation of a sustainable development economy.
\end{abstract}

\section{Introduction}

Sustainable development is a concept that originated in 1970-1980s against the background of recognition of development problems of society and science, limited nature of natural resources and ecological situation by the world community [1]. Sustainable development is a global strategy that was first defined in the 1987 UN Commission on Environment and Development report "Our Common Future". Essence of this strategy is formation of economic, social, political trends and solutions that would meet present needs and at the same time would not pose a threat to future generations. Thus, sustainable development refers to economic growth that does not harm the environment and contributes to resolution of social problems, finding a balance between economic, environmental and social development.

The "Agenda for Sustainable Development" (United Nations Development Group, 2016, https://unsdg.un.org/resources/mainstreaming-2030-agenda-sustainable-developmentreference-guide-un-country-teams), a document prepared by the UN in 2015, contains the

*Corresponding author: oyelina@yandex.ru 
nearest goals for 2030, that society needs to strive for, and outlines its main problems, which can and should be taken care of by every country and subject separately.

In addition to the 17 goals, the concept contains 169 specific tasks formulated in the form of recommendations of a global nature, but at the same time, the government of each country should set its own national goals, guided by global needs and taking into account national conditions. Each country would decide how to ensure that these global challenges are taken into account by specifying measures, strategies and recommendations for national planning processes.

On June 26, 2020, the UN website published the first Voluntary National Review of Russia's achievement of the Sustainable Development Goals (Analytical Center for the government of Russian Federation, 2020, https://sustainabledevelopment.un.org/content/documents/26421VNR_2020_Russia_Report Russian.pdf). It presents the results of monitoring indicators of socio-economic

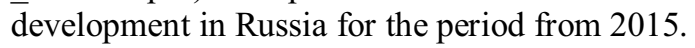

Successful implementation and realisation of the goals and objectives of sustainable development largely depends on direct participation of businesses in this process. The Organization for Economic Cooperation and Development (OECD) identifies the following areas of business involvement in activities to achieve the SDGs (sustainable development goals) [2]:

- direct foreign investments;

- combined financing;

- the concept of state support for sustainable development;

- social investments;

- responsible business conduct.

\section{Theory and hypothesis development}

At the government level in the Russian Federation, environmental problems are controlled by the current national project "Ecology". Its main directions are: elimination of landfills, disposal and recycling of waste, disposal of hazardous waste, clean air, ecologic improvement of the Volga river, preservation of the lake Baikal, other rivers and lakes, national parks and reserves, forest conservation, environmental education, environmental monitoring.

The World Business Council for Sustainable Development (WBCSD) highly values the role of the private sector and investors in achieving the SDGs, since business is becoming the main driver of economic growth, creating jobs, financial flows, creating new technologies and introducing innovations.

It is hypothesized that companies that will apply the principles of sustainable development in their work will be able to better manage their risks, predict the market, build reliable and trusting relationships with partners and employees, and thereby provide themselves with competitive advantages, including greater investment attractiveness.

Since the Russian Federation supported the UN initiative, Russian businesses began to actively participate in the agenda and integrate sustainable development goals into their activities.

A number of studies on the motives and behavior of economic agents, as well as on the performance of their activities, show that pursuing social goals has a positive effect on the commercial efficiency of the business and on the financial well-being of the owner $[3,4]$. Commercial organizations can thrive, increase competitiveness and legitimacy by acting in a socially responsible manner [5,6,7].

At the same time, there are a number of studies that demonstrate that a company's willingness to implement global and national sustainable development goals is manifested 
only if this does not contradict their commercial goals. And the smaller a company is in size, the less willing it is to compromise commercial goals in favor of sustainability, and that behavior is even more prominent in small and medium-sized enterprises [8].

For example, in a study [9], it was found that excessive attention to social purpose to the point of disregard of a business model in the early stages of a new organization can be detrimental to subsequent activities. In a study [10] it was found that pro-socially motivated entrepreneurs face more difficulties in the startup process than those that follow purely economic motives. Also it was shown that excessive emphasis on social goals can weaken the enterprise and possibly lead to commercial failure [11].

Thus, within the framework of this article, the authors consider it necessary to go beyond the concept of win-win between social and business goals and adhere to the hypothesis that for small and medium-sized businesses, an orientation towards sustainability is possible only if it correlates with productivity and profitability. In order to motivate small and mediumsized businesses to participate in achieving sustainable goals, it is necessary to provide conditions that reduce possible losses in commercial efficiency - productivity and profitability - caused by making business decisions that balance economic, environmental and social outcomes. Such conditions can be provided by influence of two factors: an intrinsic factor, that is selection of effective business models and an external factor, that is implementation of state support programs for enterprises that adhere to sustainable development goals.

\section{Materials and methods}

The Sustainable Development Goals are a global call for action to eradicate poverty, protect our planet, improve quality of life and improve prospects for all people around the world. As a result of the implementation of the SDGs, some amount of progress has been observed in many areas, but in general, actions to achieve the Goals have not yet reached the required pace and scale. At the 2019 SDG Summit, 2020 heralded the start of a decade of decisive action to achieve the 2030 Goals.

After analyzing the existing UN SDGs, the authors have identified those that should be attributed to the field of solving environmental problems. In our opinion, these should include:

SDG 6 - clean water and sanitation;

SDG 7 - renewable energy sources;

SDG 12 - responsible consumption and production;

SDG 13 - fighting climate change

SDG 14 - conserving marine ecosystems

SDG 15 - conserving land ecosystems.

This article examines and analyzes the results, problems and potential opportunities for small and medium-sized businesses participation in achieving the SDGs in the Russian Federation in the context of global dynamics of these processes.

The conclusions and methods of the authors of this article are based on the results of the UNGC The United Nations Global Compact - Accenture Strategy CEO Study on Sustainability, which was conducted in 2015 and 2019, and analyzed potential opportunities for business participation and motivation in implementation of the SDGs [12]. Thus, in 2015, the survey showed a high level of engagement and optimism among the respondents and their desire to get involved in the achievement of the SDGs, however, the 2019 survey showed negative dynamics in all 17 indicators, including those emphasised by the authors as directly related to solving environmental problems.

At the same time, we carried out a sampling and analysis of statistical data on the levels of economic activity and performance of small and medium-sized enterprises for 2017-2019 
in the context of general dynamics of performance indicators of all enterprises and organizations of the Russian Federation categorised as E OKVED 2 (Water supply; wastewater disposal, organization of collection and waste disposal, activities to eliminate pollution).

We have analyzed:

1. Expenditure on environmental protection in the Russian Federation (Table 2) in 2013 2019 in the context following activities:

- Conservation of biodiversity and protection of natural areas;

- Air protection and climate change prevention;

- Collection and treatment of wastewater;

- Waste management;

- Protection and rehabilitation of land, surface and ground waters;

- Other areas of environmental protection.

2. Current (operating) expenditure on environmental protection, including payment for environmental services (Table 3 ) in general and for a number of districts of the Russian Federation in 2013 - 2019:

- Central Federal District;

- Ural federal district;

- Siberian Federal District;

- Far Eastern Federal District.

3. Contribution of SMEs (including micro-enterprises) to the studied categories of activities in terms of turnover of products by type of economic activity, in total and code $\mathrm{E}$ in 20172019 (Table 4) in comparison with analogous data for large enterprises in Russia (Table $5)$.

\section{Results}

The degree of business engagement in achieving the SDGs in 2015 and 2019, as well as the target values for 2030 in the context of implementation of the UN SDGs in Russia[13], obtained from the UNGC The United Nations Global Compact - Accenture Strategy CEO Study on Sustainability and summarized by the authors, are presented in the following table:

Table 1. Dynamics of assessing the potential of business participation in achieving the SDGs.

\begin{tabular}{|c|c|c|c|c|}
\hline ஜ & SDG in Russia & $\begin{array}{c}\text { Business } \\
\text { engagement in } \\
\text { participation } \\
\text { (positive } \\
\text { answer, \% of } \\
\text { respondents), } \\
\text { according to } \\
\mathbf{2 0 1 5} \text { data } \\
\end{array}$ & $\begin{array}{c}\text { Business } \\
\text { engagement in } \\
\text { participation } \\
\text { (positive } \\
\text { answer, } \% \text { of } \\
\text { respondents), } \\
\text { according to } \\
2019 \text { data } \\
\end{array}$ & $\begin{array}{l}\text { Target value of } \\
\text { the interest and } \\
\text { business } \\
\text { participation by } \\
2030\end{array}$ \\
\hline 6 & $\begin{array}{l}\text { Ensuring the availability and } \\
\text { sustainable use of water and } \\
\text { sanitation for all }\end{array}$ & $42 \%$ & $32 \%$ & $\begin{array}{l}100 \% \text { purity of } \\
\text { water resources } \\
\text { Providing water } \\
\text { beyond our value } \\
\text { chain to the } \\
\text { communities and } \\
\text { ecosystems where } \\
\text { we operate }\end{array}$ \\
\hline 7 & $\begin{array}{l}\text { Ensuring universal access to } \\
\text { affordable, reliable, } \\
\text { sustainable and modern } \\
\text { energy for all }\end{array}$ & $47 \%$ & $40 \%$ & $\begin{array}{l}100 \% \text { renewable } \\
\text { energy sources }\end{array}$ \\
\hline
\end{tabular}




\begin{tabular}{|c|c|c|c|c|}
\hline 12 & $\begin{array}{l}\text { Ensuring the transition } \\
\text { towards } \\
\text { consumption and productionable } \\
\text { patterns }\end{array}$ & $51 \%$ & $50 \%$ & $\begin{array}{l}\text { Ensure sustainable } \\
\text { management of } \\
\text { resource efficiency }\end{array}$ \\
\hline 13 & $\begin{array}{l}\text { Take urgent action to } \\
\text { combat climate change and } \\
\text { its impacts }\end{array}$ & $63 \%$ & $48 \%$ & $1.5^{\circ} \mathrm{C}$ \\
\hline 14 & $\begin{array}{l}\text { Conserve and rationally use } \\
\text { the oceans, seas and marine } \\
\text { resources for sustainable } \\
\text { development }\end{array}$ & $16 \%$ & $13 \%$ & $\begin{array}{l}100 \% \quad \text { ocean } \\
\text { pollution protection }\end{array}$ \\
\hline 15 & $\begin{array}{l}\text { Protect, restore and promote } \\
\text { sustainable use of terrestrial } \\
\text { ecosystems, sustainably } \\
\text { manage forests, combat } \\
\text { desertification, halt and } \\
\text { reverse land degradation and } \\
\text { halt biodiversity loss }\end{array}$ & $22 \%$ & $21 \%$ & $\begin{array}{l}\text { Sustainable } \\
\text { management of all } \\
\text { types of forests: } \\
\text { stop deforestation, } \\
\text { restore degraded } \\
\text { forests and } \\
\text { significantly } \\
\text { increase global } \\
\text { reforestation }\end{array}$ \\
\hline
\end{tabular}

The 2019 CEO Study on Sustainability draws on the findings of 1,000 people, including executives from 21 industries and 99 countries and an additional 1,500 entrepreneurs, who have responded to the UN Global Compact initiative.

Interest of business leaders in sustainability peaked in 2016 (70\% of executives believed that the Global Goals would provide a clear framework for coordinating sustainability efforts and linked it to business success, they were ready to reimagine their business management efforts and start considering SDGs in their strategies and business processes, but results were not as positive in 2019 study. Business leaders and owners in 2019 note that fulfillment of business objectives does not fully correspond to the SDGs.

In $2016,49 \%$ of the surveyed business representatives in the world said that businesses will play a leading role in achieving the global SDGs, 78\% saw opportunities within their companies to contribute to the achievement of global goals, $90 \%$ expressed their commitment to achieving the SDGs.

In 2019 , only $48 \%$ are introducing elements of achieving the SDGs into business processes, only $21 \%$ believe that business currently plays a decisive role in contributing to the achievement of the SDGs, and only $71 \%$ of leaders are committed to achieving the global SDGs.

At the same time, the study shows that the main contributors to the negative dynamics of these indicators are respondents representing small and medium-sized enterprises, $63 \%$ of whom name lack of financial resources as the main obstacle.

The authors made a number of significant conclusions after analysing statistical data on performance of enterprises and organizations in the Russian Federation on the period of 2013-2019, contribution of small and medium-sized enterprises to activities related to solving environmental problems and the dynamics of these indicators in general and for SMEs:

1. Expenditure on environmental protection in the Russian Federation in the period of 20132019 has a pronounced positive trend (Table 2). With an average annual growth rate of $10.74 \%$, for the period under review, the total growth was $82.3 \%$. A significant increase is observed in 2015 and in 2019. 
Table 2. Dynamics of expenditure on environmental protection in the Russian Federation.

\begin{tabular}{|l|c|c|c|}
\hline \multicolumn{1}{|c|}{ Expenditure category } & $\mathbf{2 0 1 4}$ & $\mathbf{2 0 1 5}$ & $\mathbf{2 0 1 9}$ \\
\hline $\begin{array}{l}\text { Other areas of environmental protection, } \\
\%\end{array}$ & 135.09 & 102.00 & 159.43 \\
\hline $\begin{array}{l}\text { Conservation of biodiversity and } \\
\text { protection of natural areas \% }\end{array}$ & 122.78 & 129.30 & 107.69 \\
\hline $\begin{array}{l}\text { Air protection and climate change } \\
\text { prevention, \% }\end{array}$ & 120.55 & 91.42 & 107.51 \\
\hline $\begin{array}{l}\text { Collection and treatment of wastewater, } \\
\%\end{array}$ & 109.34 & 104.78 & 104.17 \\
\hline Waste management, \% & 117.97 & 112.48 & 122.33 \\
\hline $\begin{array}{l}\text { Protection and rehabilitation of land, } \\
\text { surface and ground waters, \% }\end{array}$ & 107.82 & 105.12 & 115.69 \\
\hline Total, million rubles & 559702.99 & 582128.00 & 873547.99 \\
\hline Chain growth rates, \% & 116.81 & 104.01 & 121.17 \\
\hline Baseline growth rates (to 2013), \% & 116.81 & 121.49 & 182.30 \\
\hline
\end{tabular}

2. Current (operating) expenditure on environmental protection, including payments for environmental services (Table 3 ) in general and by observed districts (The Central Federal District, the Ural Federal District, the Siberian Federal District, the Far Eastern Federal District) of the Russian Federation in 2013- 2019 display steadily increasing dynamics with exceptional values:

- In 2016, in the category "Protection of the environment from noise, vibration and other types of physical impact in the Russian Federation, in total" the growth rate is $179.47 \%$ with a predominant share in the Far Eastern Federal District;

- In 2015, in the category "Conservation of biodiversity and protection of natural areas in the Russian Federation, total" the growth rate was $344.3 \%$ with a predominant share in the Far Eastern Federal District;

- In the category "Ensuring the radiation safety of the environment in the Russian Federation, in total", cost indicators display more growth in the Ural and Siberian federal districts;

- In the category "Waste management in the Russian Federation, total" in 2017 the growth rate is $128.64 \%$ and in 2019 - 134.89\%, with most expenses conducted in the Central and Ural federal districts.

Table 3. Current (operating) expenditure on environmental protection in the Russian Federation, including payment for environmental services, indexed.

\begin{tabular}{|l|l|l|l|l|l|l|l|}
\hline $\begin{array}{c}\text { Type of } \\
\text { expenditure } \\
\text { for a number } \\
\text { of russian } \\
\text { districts }\end{array}$ & $\mathbf{2 0 1 3}$ & $\mathbf{2 0 1 4}$ & $\mathbf{2 0 1 5}$ & $\mathbf{2 0 1 6}$ & $\mathbf{2 0 1 7}$ & $\mathbf{2 0 1 8}$ & $\mathbf{2 0 1 9}$ \\
\hline $\begin{array}{l}\text { Protection of } \\
\text { the } \\
\text { environment } \\
\text { from noise, } \\
\text { vibration and } \\
\text { other types of } \\
\text { physical } \\
\text { impact in } \\
\text { Russia, total }\end{array}$ & 100.00 & 105.36 & 92.38 & $\mathbf{1 7 9 . 4 7}$ & 54.61 & 144.00 & 103.35 \\
\hline $\begin{array}{l}\text { Central } \\
\text { Federal } \\
\text { District }\end{array}$ & 17.57 & 22.83 & 28.67 & 14.45 & 31.32 & 19.68 & 24.15 \\
\hline
\end{tabular}




\begin{tabular}{|c|c|c|c|c|c|c|c|}
\hline $\begin{array}{l}\text { Ural Federal } \\
\text { District }\end{array}$ & 12.49 & 5.42 & 6.78 & 20.58 & 5.03 & 5.84 & 8.74 \\
\hline $\begin{array}{l}\text { Siberian } \\
\text { Federal } \\
\text { District }\end{array}$ & 11.40 & 9.41 & 10.73 & 5.10 & 8.10 & - & - \\
\hline $\begin{array}{l}\text { Far Eastern } \\
\text { Federal } \\
\text { District }\end{array}$ & 4.01 & 7.58 & 6.48 & 24.94 & 6.84 & - & - \\
\hline $\begin{array}{l}\text { Conservation } \\
\text { of biodiversity } \\
\text { and protection } \\
\text { of natural } \\
\text { areas in } \\
\text { Russia, total }\end{array}$ & 100.00 & 137.57 & 344.30 & 35.35 & 105.21 & 98.09 & 111.03 \\
\hline $\begin{array}{l}\text { Central } \\
\text { Federal } \\
\text { District }\end{array}$ & 9.71 & 9.27 & 5.15 & 14.34 & 9.17 & 12.31 & 12.90 \\
\hline $\begin{array}{l}\text { Ural Federal } \\
\text { District }\end{array}$ & 6.99 & 5.06 & 5.01 & 10.70 & 23.18 & 19.47 & 22.45 \\
\hline $\begin{array}{l}\text { Siberian } \\
\text { Federal } \\
\text { District }\end{array}$ & 22.55 & 13.47 & 5.87 & 19.17 & 16.42 & - & - \\
\hline $\begin{array}{l}\text { Far Eastern } \\
\text { Federal } \\
\text { District }\end{array}$ & 20.70 & 30.94 & 72.54 & 24.40 & 22.31 & - & - \\
\hline $\begin{array}{l}\text { Ensuring the } \\
\text { radiation } \\
\text { safety of the } \\
\text { environment } \\
\text { in the Russian } \\
\text { Federation, } \\
\text { total }\end{array}$ & 100.00 & 108.18 & 87.59 & 113.98 & 103.65 & 124.00 & 107.71 \\
\hline $\begin{array}{l}\text { Central } \\
\text { Federal } \\
\text { District }\end{array}$ & 8.21 & 18.18 & 15.16 & 23.44 & 22.06 & 18.72 & 18.54 \\
\hline $\begin{array}{l}\text { Ural Federal } \\
\text { District }\end{array}$ & 25.41 & 16.57 & 13.84 & 14.24 & 13.93 & 19.95 & 18.96 \\
\hline $\begin{array}{l}\text { Siberian } \\
\text { Federal } \\
\text { District }\end{array}$ & 19.19 & 13.79 & 24.82 & 21.62 & 24.42 & - & - \\
\hline $\begin{array}{l}\text { Far Eastern } \\
\text { Federal } \\
\text { District }\end{array}$ & 6.58 & 7.02 & 2.90 & 2.82 & 2.47 & - & - \\
\hline $\begin{array}{l}\text { Waste } \\
\text { management } \\
\text { in Russia, } \\
\text { total }\end{array}$ & 100.00 & 113.37 & 113.41 & 105.64 & 128.64 & 105.21 & 134.89 \\
\hline $\begin{array}{l}\text { Central } \\
\text { Federal } \\
\text { District }\end{array}$ & 20.47 & 18.96 & 19.48 & 19.20 & 17.67 & 20.49 & 24.18 \\
\hline $\begin{array}{l}\text { Ural Federal } \\
\text { District }\end{array}$ & 13.77 & 15.68 & 15.22 & 20.33 & 23.66 & 17.90 & 16.37 \\
\hline $\begin{array}{l}\text { Siberian } \\
\text { Federal } \\
\text { District }\end{array}$ & 24.12 & 22.34 & 21.41 & 17.24 & 15.56 & - & - \\
\hline
\end{tabular}




\begin{tabular}{|l|c|c|c|c|c|c|c|}
\hline $\begin{array}{l}\text { Far Eastern } \\
\text { Federal } \\
\text { District }\end{array}$ & 4.58 & 4.23 & 6.84 & 5.86 & 5.50 & - & - \\
\hline Russia, total & $\mathbf{1 0 0 . 0 0}$ & $\mathbf{1 0 5 . 1 8}$ & $\mathbf{1 1 1 . 1 4}$ & $\mathbf{1 0 4 . 5 3}$ & $\mathbf{1 0 9 . 6 4}$ & $\mathbf{1 0 5 . 6 8}$ & $\mathbf{1 1 1 . 1 3}$ \\
\hline $\begin{array}{l}\text { Central } \\
\text { Federal } \\
\text { District }\end{array}$ & 19.04 & 17.99 & 17.93 & 17.83 & 18.00 & 18.76 & 20.20 \\
\hline $\begin{array}{l}\text { Ural Federal } \\
\text { District }\end{array}$ & 18.98 & 18.72 & 19.85 & 22.06 & 21.35 & 18.65 & 18.28 \\
\hline $\begin{array}{l}\text { Siberian } \\
\text { Federal } \\
\text { District }\end{array}$ & 16.54 & 16.79 & 15.62 & 14.87 & 15.19 & - & - \\
\hline $\begin{array}{l}\text { Far Eastern } \\
\text { Federal } \\
\text { District }\end{array}$ & 4.72 & 5.16 & 6.67 & 5.67 & 5.70 & - & - \\
\hline
\end{tabular}

3. While noted positive dynamics of indicators reflecting the growth of level of engagement (in terms of costs) of enterprises and organizations in activities related to the environment is observed overall, small and medium-sized enterprises display low growth rate of performance indicators. According to the category "Dynamics of SME product turnover by type of economic activity, total and in category E", there is a negative trend in category $\mathrm{E}$ in 2017-2019 (Table 4).

Table 4. Dynamics of the turnover of products of SMEs by type of economic activity, in total and code E.

\begin{tabular}{|l|c|c|c|}
\hline \multicolumn{1}{|c|}{ Name } & $\mathbf{2 0 1 7}$ & $\mathbf{2 0 1 8}$ & $\mathbf{2 0 1 9}$ \\
\hline $\begin{array}{l}\text { Total by type of economic activity, billion } \\
\text { rubles }\end{array}$ & 6276.85 & 6622.04 & 6141.60 \\
\hline $\begin{array}{l}\text { Water supply; wastewater disposal, } \\
\text { organization of collection and waste } \\
\text { disposal, activities to eliminate pollution, } \\
\text { billion rubles }\end{array}$ & 48.52 & 45.89 & 48.71 \\
\hline $\begin{array}{l}\text { Chain growth rate of the SME turnover by } \\
\text { type of economic activity, total }\end{array}$ & 1.00 & 1.05 & 0.93 \\
\hline $\begin{array}{l}\text { Chain growth rate of the SME turnover by } \\
\text { type of economic activity, category E }\end{array}$ & 1.00 & 0.95 & 1.06 \\
\hline $\begin{array}{l}\text { Baseline growth rate of the SME turnover } \\
\text { by type of economic activity, total }\end{array}$ & 1.00 & 1.05 & 0.98 \\
\hline $\begin{array}{l}\text { Baseline growth rate of the SME turnover } \\
\text { by type of economic activity, category E }\end{array}$ & 1.00 & 0.95 & 1.00 \\
\hline
\end{tabular}

At the same time, in the structure of SME activities, the share of category $E$ is about 1 . In general, for enterprises and organizations of the Russian Federation, according to the category "Dynamics of SME product turnover by type of economic activity in total and by code E", there is a stable positive trend (Table 5). 
Table 5. Dynamics of the turnover of products of large russian enterprises by type of economic activity, in total and code E.

\begin{tabular}{|l|c|c|c|}
\hline \multicolumn{1}{|c|}{ Name } & $\mathbf{2 0 1 7}$ & $\mathbf{2 0 1 8}$ & $\mathbf{2 0 1 9}$ \\
\hline $\begin{array}{l}\text { Total by type of economic activity, billion } \\
\text { rubles }\end{array}$ & 154364.1 & 186821.5 & 197732.9 \\
\hline $\begin{array}{l}\text { Water supply; wastewater disposal, } \\
\text { organization of collection and waste disposal, } \\
\text { activities to eliminate pollution, billion rubles }\end{array}$ & 968.6 & 1147.5 & 1166.4 \\
\hline $\begin{array}{l}\text { Chain growth rates of the turnover by type of } \\
\text { economic activity, total }\end{array}$ & 1 & 1.210265 & 1.058405 \\
\hline $\begin{array}{l}\text { Chain growth rates of the turnover by type of } \\
\text { economic activity, category E }\end{array}$ & 1 & 1.184731 & 1.016437 \\
\hline $\begin{array}{l}\text { Baseline growth rates of the turnover by type } \\
\text { of economic activity, total }\end{array}$ & 1 & 1.210265 & 1.280951 \\
\hline $\begin{array}{l}\text { Baseline growth rates of the turnover by type } \\
\text { of economic activity, category E }\end{array}$ & 1 & 1.184731 & 1.204205 \\
\hline
\end{tabular}

The analysis of statistical data on the contribution and forms of participation of SMEs in solving environmental problems and the formation of sustainable development trends in achieving the SDGs in the Russian Federation related to solving environmental problems shows extremely low participation and motivation in this sector. This is in line with studies of global trends indicating a decline in business and economic activity towards the achievement of the SDGs, especially in the SME sector. This is due to objective reasons for the priority of business goals associated with achieving productivity and profitability as a condition of their survival.

In the Discussion and Conclusion section, the authors consider the possibilities for overcoming these trends through external influence tools in the form of government support and internal transformations of business processes and the use of effective models.

\section{Discussion and Conclusion}

Our study of participation of russian SMEs in achieving the SDGs that involve solution of environmental problems of society raises the following questions:

- Is it possible to involve SMEs in achieving the SDGs?

- What are the possible forms of participation of SMEs in activities related to environmental protection?

- Is commercially successful implementation of business projects adhering to SDGs possible?

- Are effective business models for SMEs in fields related to environmental protection possible?

Practice and international experience of countries with developed market economies show that maintaining an acceptable share of small and medium-sized enterprises requires governmental and other types of support. This sector of different country economies is formed and retains its share mostly due to government policy. Studies of the level and potential growth of the SME sector in the Russian Federation (Stolypin Institute of Growth Economics, 2018, https://stolypin.institute/wp-content/uploads/2018/07/issledovanie-iermsp-27.07.18.pdf) show its low level relative to the average in the world, which allows to conclude that there is significant development potential. An increase of at least 2.9 times is required to achieve the world average level. At the same time, inclusion of business in SDGs impies compensatory decisions and programs to reduce possible losses due to implementation of strategies within the framework of sustainable development. This allows us to conclude that there is a need for special attention on the part of the government to 
address issues connected to involving SMEs in achieving national SDGs.

The state policy of the Russian Federation of supporting SMEs is implemented in two program documents: "Strategy for the development of small and medium-sized businesses in the Russian Federation" (2016) and the national project "Small and medium-sized businesses and support for individual entrepreneurial initiative" (2018). In addition to critical assessments of achieving the goals of these programs by the Accounting Chamber of Russian Federation, these documents require further development in order to identify and address issues connected to including SMEs in the achievement of the SDGs in the field of ecology and in general $[14,15]$.

Forms of participation of SMEs in activities related to environmental protection also require special attention, since in this case SMEs should play a special role, leveraging implementation of innovative technologies to provide environmental services such as organizing waste collection and disposal or services for eliminating pollution.

For example, if there are drivers for development of SMEs in the niche of environmental entrepreneurship, they can provide an increase in activities like management of production and waste consumption and can contribute to solving such an urgent task as recycling, expand innovative technologies in the field of reuse of secondary material and energy waste. Tourism and recreation, which already have a target audience and do not require huge investments at the initial stage, can become another key area for development of green entrepreneurship in the SME sector. There are sufficient conditions and opportunities for development and improvement for such a trend direction as ecological tourism in the Russian Federation, which means it is possible to attract investments and entrepreneurs in this area. The result will be not only the promotion of a careful attitude to natural resources, but also development of the real sector of the economy and creation of new jobs. The development of environmentally friendly business in our country can significantly improve the environmental situation and increase competitiveness of goods and services.

Commercial success of SME business projects in the field of fulfilling the SDGs can be achieved with the help of effective business models for certain types of activities according to the classification. In particular, it is possible to recommend for consideration by SMEs such business models as:

- sharing models based on the joint consumption of resources, which create saving effect, neutralizing possible loss of efficiency connected to achieving the SDGs for SMEs;

- intermediary business models: outsourcing, agency model, dropshipping, commissioning model, franchising;

- crowdfunding and crowdsourcing models will allow attracting third-party resources and contribute to formation and implementation of effective socially-oriented projects.

\section{References}

1. The Future We Want resolution A/RES/66/288 (United Nations General Assembly, 2012)

2. OECD. Development Co-operation Report 2016, 139-149 (2016) DOI: $10.1787 /$ dcr-2016-13-en

3. T. Miller, M. Grimes, J. McMullen, T. Vogus, Academy of Management Review 37(4), 616-640 (2012) DOI: 10.5465/amr.2010.0456

4. D. Shepherd, Journal of Business Venturing 30(4), 489-507 (2015) DOI: 10.1016/j.jbusvent.2015.02.001

5. P. Bansal, K. Roth, The Academy of Management Journal 43(4), 717-736 (2000) DOI: $10.2307 / 1556363$ 
6. P. Berrone, A. Fosfuri, L. Gelabert, L. Gomez-Mejia, Strategic Management Journal 34(8), 891-909 (2013) DOI: 10.1002/smj.2041

7. G. Demuijnck, B. Fasterling, Journal if Business Ethics 136(4), 675-685 (2016) DOI: $10.1007 / \mathrm{s} 10551-015-2976-7$

8. T. Kautonen, S. Schillebeeckx, J. Gartner, H. Hakala, K. Salmela-Aro, K. Snellman, Journal of Business Venturing Insights 14, e00198 (2020) DOI: 10.1016/j.jbvi.2020.e00198

9. P. Munoz, G. Cacciotti, B. Cohen, Journal of Business Venturing 33(2), 149-178 (2018) DOI: 10.1016/j.jbusvent.2017.12.005

10. M. Renko, Entrepreneurship Theory and Practice 37(5), 1045-1069 (2013) DOI: 10.1111/j.1540-6520.2012.00522.x

11. D. Young, Social Enterprise: An Organizational Perspective, 19-46 (2012) DOI: $10.1515 / \mathrm{npf}$-2017—0005

12. OECD. Development Cooperation Report, 119-136 (2016) DOI: $10.1787 / \mathrm{dcr}-$ 2016-12-en

13. S. Bobylev, L. Grigoriev, Analytical Center under the Government of the Russian Federation, Report on Human Development in the Russian Federation for 2016 (2016) https://ac.gov.ru/files/publication/a/11068.pdf

14. E. Nikolaeva, D. Pletnev, Journal of Advanced Research in Law and Economics 6(4), 768-774 (2015) DOI: 10.14505/jarle.v6.4(14).06

15. V. Barkhatov., D. Pletnev, A. Campa, Procedia - Social and Behavioral Sciences 221, 29-38 (2016) DOI: 10.1016/j.sbspro.2016.05.087 